\title{
Energy-saving technology of cleaning water basin and enrichment with algae raw materials for biogas production
}

\author{
Anastasiya Mylayeva ${ }^{1,{ }^{*}}$, Nadezhda Kuznetzova $^{1}$, Tatiana Shchukina ${ }^{1}$, Dmitriy Drapalyuk ${ }^{1}$ \\ ${ }^{1}$ Voronezh State Technical University, 84, 20 let Oktjabrja, 394006, Voronezh, Russia
}

\begin{abstract}
Reproductive ability of cyanobacteriums are one of main parameters of ecological conditions of water-basin and it is especially actually for artificial water objects. Changes of concentrations of bluegreen algae in warm year period allows to trace zones of strong pollution without additional attraction of chemical laboratory. Thus it is enough significant mean have prognosis of situation evolution with use cyanobacteriums. With this aim it was received equation of change concentration of blue-green algae in dependence of time in taking to account different degree content of dissolved matter, and possible temperature stratification for considered water objects by different weather condition. On accordance of calculated data by predictable weather and temperature conditions of summer season it is possible to estimate consequences of pollutions by blue-green algae, and to make recommendations for improvement this situation. At prediction of possible ecological disaster it is offered to use innovative method of elimination the consequences, based on hydro-mechanical filtration. As nozzle for pollution catching it is argued the necessity of use milled cane, which source is exceed in shallow water. It should be note, that this type filter can not only retard different fine impurities and blue-green algae, but absorb ions of heavy metals. Moreover, nozzle's filler is exposed by ecological safety utilization. Replaceable cartridges with milled cane is able to additionally clean coastline from rough water flora and to direct in consequence all biomass to units of biogas production.
\end{abstract}

\section{Introduction}

Increased consumption of resources, natural fossils, fresh water and active manufacturing activity accompanies with increase of anthropogenic load to environment. In consequence on it there is more and more gives attention to decrease blowouts of different pollutants to atmosphere, transition factories to waste-less or waste-small manufacturing, increase efficiency of wastewater sewage plants. It is appear the necessity to considering different methods in the search of technologies for elimination consequences of negative influence on environment, where one of the main task is recovery of water object ecosystems. For example, in Voronezh city main water source is Voronezh water basin and

\footnotetext{
*Corresponding author: n.milya@bk.ru
} 
Don river. Their riverbeds have significant longitude through urban territories, which cause relative higher level of water spoil and low hygienic security.

\section{Materials and methods}

One of the most significant factors, which increase ecological risk, is throw water from city sewerage after water treatment plant. At the same time the sewage of right-coast part of Voronezh city in volume of 400 ths. $\mathrm{m}^{3} /$ day. allocated to the Don river, and in left-coast part - to the Voronezh water basin in volume 305 ths. $\mathrm{m}^{3} /$ day. Analysis of hydro-chemical condition of water in control gates lower than $500 \mathrm{~m}$ of dumps of left-coast and right-coast sewage treatment plant, that level of sewage cleaning is not enough (table 1). During the dump of spoil matter through the outlets of local sewage treatment plant it is seen the exceeding 10 of 14 aim parameters [1].

Sewage from waste water treatment plant, which contain large quantity of organic, promote to rapid growth of blue-green algae. Entrance of organic matters to water-basin create comfort nutrient medium for the reproduction of cyanobacteriums, which absorb solar radiation. Concentration of blue-green algae, which is in normal limit, have positive influence on water condition. By active non-controlled reproduction of cyanobacteriums, typical for the high value of dissolved organic matters, decrease content of oxygen in water, rise level of bottom sediment, appear unpleasant odor and periodical mortality of river fauna. Absent of efficient low-cost methods of fighting with blue-green algae complicates ecological condition of artificial water basins. As solution of current problem it is offered to design system of local cleaning of water basin on base of filters with absorption nozzle from milled cane. By offered scheme of cleaning will be solute some problems simultaneously: collection blue-green algae, cleaning water from harmful matters, rational use of cane and cleaning of coast from it, ecological safe utilization of getting biomass through biogas production and incorporation sludge into soil as fertilizer.

Table 1. Content of different matters in sewage water after cleaning on sewage treatment plant at 2017 year.

\begin{tabular}{|c|c|c|c|c|c|}
\hline \multirow{2}{*}{ Pollution matter } & \multicolumn{2}{|c|}{$\begin{array}{l}\text { Concentration of pollution } \\
\text { matters. } \mathrm{mg} / \mathrm{dm}^{3}\end{array}$} & \multirow{2}{*}{$\begin{array}{c}\text { Permissible } \\
\text { concentration } \\
\text { fish water basin } 1^{\text {st }} \\
\text { category }(\mathrm{px}) . \\
\mathrm{mg} / \mathrm{dm}^{3}\end{array}$} & \multicolumn{2}{|c|}{$\begin{array}{l}\text { Excess of Permissible } \\
\text { concentration } \\
\text { px in «n» quantity. times }\end{array}$} \\
\hline & $\begin{array}{l}\text { Left-coast part } \\
\text { of Voronezh } \\
\text { wastewater } \\
\text { sewage plant }\end{array}$ & $\begin{array}{l}\text { Right-coast } \\
\text { part of } \\
\text { Voronezh } \\
\text { wastewater } \\
\text { sewage plant }\end{array}$ & & $\begin{array}{c}\text { Left-coast } \\
\text { part of } \\
\text { Voronezh } \\
\text { wastewater } \\
\text { sewage plant }\end{array}$ & $\begin{array}{c}\text { Right-coast } \\
\text { part of } \\
\text { Voronezh } \\
\text { wastewater } \\
\text { sewage plant }\end{array}$ \\
\hline $\begin{array}{l}\text { Suspended } \\
\text { solids }\end{array}$ & 20.82 & 11.8 & 12.55 & 1.7 & - \\
\hline Dry residue & 788.3 & 535 & 1000 & - & - \\
\hline Chlorides & 139.2 & 84.14 & 300 & - & - \\
\hline Sulphates & 92.4 & 58.98 & 100 & - & - \\
\hline $\begin{array}{l}\text { Ammonium } \\
\text { nitrogen }\end{array}$ & 10.25 & 2.64 & 0.39 & 26.3 & 6.8 \\
\hline Nitrate-ion & 31.93 & 33.59 & 40 & - & - \\
\hline Nitrite-ion & 0.61 & 0.563 & 0.08 & 7.6 & 7.0 \\
\hline $\begin{array}{c}\text { Anion } \\
\text { surfactant }\end{array}$ & 0.258 & 0.071 & 0.1 & 2.6 & 0.7 \\
\hline $\begin{array}{c}\text { Biologic } \\
\text { consumption of }\end{array}$ & 32.26 & 7.31 & 3.0 & 10.8 & 2.4 \\
\hline
\end{tabular}




\begin{tabular}{|c|c|c|c|c|c|}
\hline oxygen total & & & & & \\
\hline Cuprum & 0.039 & 0.006 & 0.001 & 39.0 & 6.0 \\
\hline Zinc & 0.05 & 0.016 & 0.01 & 5.0 & 1.6 \\
\hline Fe total & 0.802 & 0.115 & 0.1 & 8.0 & 1.2 \\
\hline Oil products & 0.149 & 0.071 & 0.05 & 3.0 & 1.4 \\
\hline Phosphates (P) & 1.19 & 2.14 & 0.2 & 6.0 & 10.7 \\
\hline
\end{tabular}

\section{Results}

Results of ongoing research of Voronezh water-basin [1, 2] revealed the exceed concentrations of heavy metals, that $\mathrm{Pb}, \mathrm{Zn}, \mathrm{Ni}$. For example, in sand bottom sedimentation these parameters are in limits from 0,3 to $2,5 \mathrm{mg} / \mathrm{kg}$, and in oozy from 0,38 to $18 \mathrm{mg} / \mathrm{kg}$ [2]. Aggravation of ecological situation, siltation the riverbed and growth of squares of alluvial islands promote to distribution of rigid forms of flora, reduction of species diversity of river's flora and fauna.

The consequence of slowed water exchange, specified for artificial objects, and significant content of dissolver organic matters in Voronezh water-basin happens wealthy reproduction of blue-green algae in warm period. Their high reproductive ability called not only high content of dissolved organic matters of different origin, but small depth on major part of water area and good warming up of reach by solar radiation [3...6]. These listed favorable conditions promote active formation of blue-green algae and growth of their concentration in summer from $20 \mathrm{mg} / 1$ [3..6], and in range of most unfavorable locations up to $50 \mathrm{mg} / \mathrm{l}$.

Reproduction process of blue-green algae in surface layers of water objects in warm season could be consider by solution of differential equation

$$
\frac{d C}{d t}=K m+\frac{C}{\tau},
$$

where $C$-concentration of blue-green algae in time moment $t, \mathrm{~g} / \mathrm{m}^{3} ; t$ - time in day , from spring season day, average day temperature not more $10{ }^{\circ} \mathrm{C} ; \mathrm{K}$-dimensionless coefficient of temperature stratification of reproduction cyanobateriums in current water environment; $\tau$ - life time of cyanobacteriums' colonies, days.; $m$ - mass speed of formation blue-green algae in $1 \mathrm{~m}^{3}$ water environment, $\mathrm{g} /\left(\right.$ day. $\left.\mathrm{m}^{3}\right) ; C / \tau$ - quantity of algae with active reproductive ability in $1 \mathrm{~m}^{3}$ and during time period $\tau, \mathrm{g} /\left(\right.$ day. $\left.\mathrm{m}^{3}\right)$.

Equation solution (1) is

$$
C=c e^{\frac{t}{\tau}}-K m \tau
$$

where $c$ - constant of integrationя.

In enough accurate approximation we accept, that at begin of season at average air temperature $10^{\circ} \mathrm{C}$ in water is absent blue-green algae. Then by $t=0$ their concentration $C=0$.

By statement to equation (2) of current start term we will get follow equation 


$$
C=K m \tau\left(e^{\frac{t}{\tau}}-1\right)
$$

Used equation (3) we consider some variants of turn of events with strong and weak pollution of water basin with organic matter and different coefficient of temperature stratification.

Mass speed of formation blue-green algae in depend of quantity of dissolved matters can be in board of 0,1 to $0,5 \mathrm{~g} /\left(\right.$ day. $\left.\mathrm{m}^{3}\right)$. Coefficient of temperature stratification $K$ in hot weather conditions, more favorable for life of cyanobacteriums, we accept equal 1. By moderate temperature mode, which respond to climate norm for middle zone of Russia $K=0,75$, by temperature mode lower climate norm $K=0,5$. Taking into consideration, that last years fixed rise of air temperature in warm year period, first line it should to consider most unfavorable scenario of saturation with phytoplankton. As you can see from data, presented in figure 1, high temperature in summer season can call in regarding prosperous water basin rapid reproduction blue-green algae in end period their reproductive ability. At average statistical temperature of outdoor air at summer and low content of organic matters develop of blue-green algae will not leads to more significant pollution of water basin, called by process of their life.

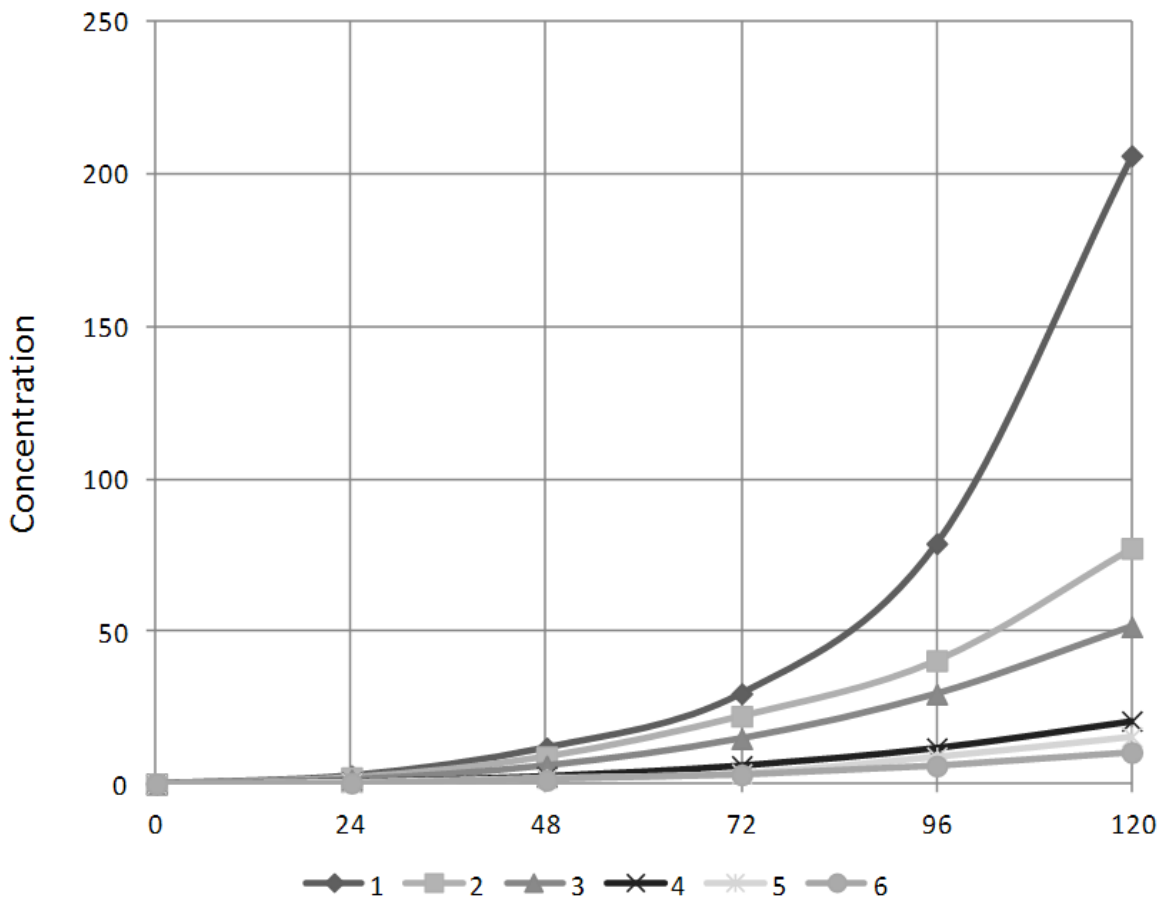

Fig. 1. Change of concentration of blue-green algae, $\mathrm{g} / \mathrm{m}^{3}$, during 120 days of warm year period at different degree of pollution with dissolved matter and coefficient of stratification in correspondence to hot climate, moderate and low climate norm and temperature mode: 1 - by strong pollution $m=0,5$ $\mathrm{g} /\left(\right.$ day. $\left.\mathrm{m}^{3}\right)$ and $K=1 ; 2$ - by strong pollution $m=0,5 \mathrm{~g} /\left(\right.$ day. $\left.\mathrm{m}^{3}\right)$ and $K=0,75 ; 3$ - by strong pollution $m=0,5 \Gamma /\left(\right.$ day. $\left.\mathrm{m}^{3}\right)$ и $K=0,5 ; 4$ - by $m=0,1 \mathrm{~g} /\left(\right.$ day. $\left.\mathrm{m}^{3}\right)$ and $K=1 ; 5$ - by $m=0,1 \mathrm{~g} /\left(\right.$ day. $\left.\mathrm{m}^{3}\right)$ and $K=0,75$; 4 - by $m=0,1 \mathrm{~g} /\left(\right.$ day. $\left.\mathrm{m}^{3}\right)$ and $K=0,5$. 


\section{Discussion}

By significant content of organic matter in the water-basin (figure 1), it is especially in zones of sewage dump after city sewage treatment station at hot summer period, adverse ecological situation, aggravated by life of cyanobacteriums, result to hardest conditions of survival river flora and fauna.

For the cleaning water basins out from blue-green algae and ions of heavy metals $(\mathrm{Cu}$, $\mathrm{Zn}, \mathrm{Pb}$ and so on) is offered unit (figure 2), which is compact-size mobile water-vessel or autonomous raft 1 with situated on it system of spoils catching. On the desk 1 is situated pump 2, filter and array of filters, bonded by pipeline 5 . For the intake concentrate biomass from the water's surface it is stipulated umbrella 6 with slot holes. Filter consists of three layers: grid textile on input and output of water 4, replaceable cartridge with collector with cane 3, and also tank 7 for preliminary collection of biomass. For the autonomous work of cleaning system pump should have replaceable accumulator.

Exploitation of these offered unit should make in period of vegetation of blue-green algae, it mean that in summer and autumn seasons by favorable temperature for the phytoplankton growth. Moreover there is supposed to make sorption water cleaning from heavy metals through their absorption by porous structure of vegetable raw materials, which is recommended cane ordinary from the family graminae, well-known as cane.

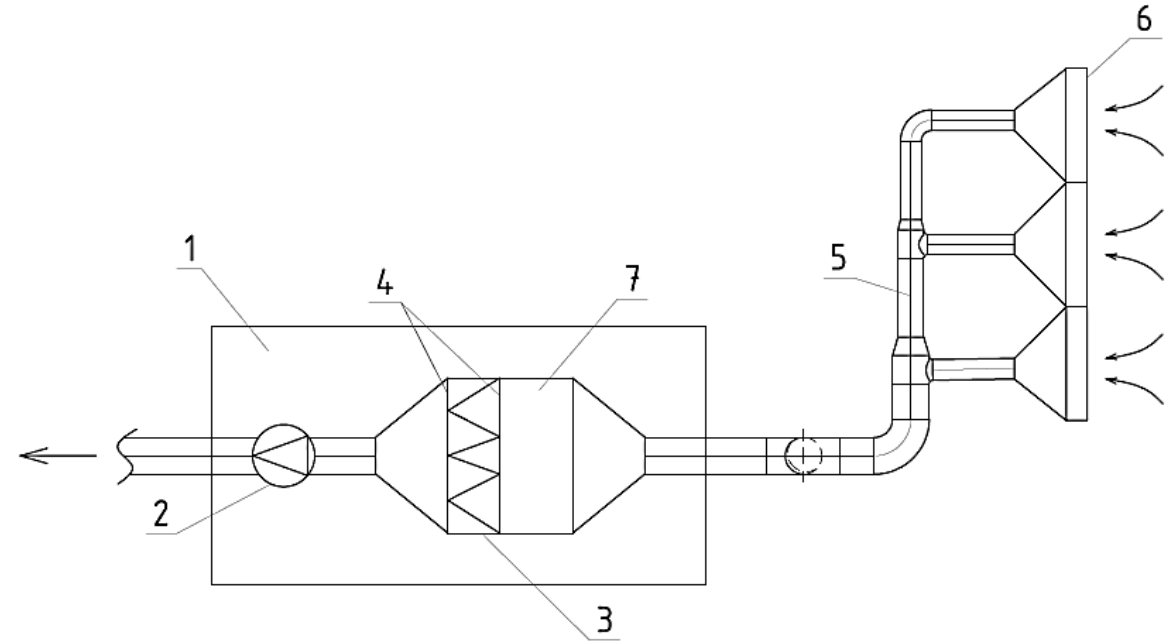

Fig. 2. Unit for water basins cleaning: 1 - deck, 2 - pump, 3 - replaceable cartridge with cane filler, 4 - grid textile, 5 - pipeline, 6 - umbrella for the water intake, 7 - tank for the filtrated biomass.

Large hydrophytes - cane in process of its life is able to extract from water in large quantities biogenic elements $(\mathrm{N}, \mathrm{P}, \mathrm{Ca}, \mathrm{K}, \mathrm{Na}, \mathrm{S}, \mathrm{Fe})$ and by this significantly decrease degree of water basin eutrophication. Thick mature cane's brushwood can accumulate in harvest biomass on 1 ha to $6 \mathrm{t}$ of different mineral matters, include $\mathrm{K}-859 \mathrm{~kg}, \mathrm{~N}-167 \mathrm{~kg}$, $\mathrm{P}-122 \mathrm{~kg}, \mathrm{Na}-451 \mathrm{~kg}, \mathrm{~S}-277 \mathrm{~kg}, \mathrm{Si}-3672 \mathrm{~kg}$ [3...6], that indicate on specific cane's necessity in these elements. Assimilate these, cane executes cleaning functions in water basin, but only with term, that its brushwood will refresh each year through the mowing. If in time delete this type of hard algae, mill them and fill with it filter cartridges, and then by floating stations, collect on they phytoplankton and absorbed another impurities can improve inhabitancy for river flora.

Collected concentrated biomass could be direct to anaerobic fermentation to methane tanks of city sewage treatment plants or in case of minimal content of harmful matters - to introduce to soil as fertilizer, because they are wealth with nutrient elements. However 
further utilization of collected water biomass is rather in biogas unit. At anaerobic fermentation of $1 \mathrm{~kg}$ of algae's dry mass by temperature $32^{\circ} \mathrm{C}$ it acquire biogas volume 0,8 $1 \mathrm{~m}^{3}$, which contents $65 \%$ methane $\left(\mathrm{CH}_{4}\right)$, up to $30 \%$ carbon dioxide $\left(\mathrm{CO}_{2}\right)$ and at average of $1 \%$ follow components $\mathrm{H}_{2}, \mathrm{H}_{2} \mathrm{~S}, \mathrm{O}_{2}$ and $\mathrm{N}_{2}$ [7...9]. Despite on insertion imbalance into water exchange and called oppression of diversity of river flora, cane have high values of methanogenesis by anaerobic fermentation, which give possibility to efficiency utilize total biomass [10...14].

Advantage of described above whole cycle of cleaning, that happens complex utilization of biomass with lowest quantity of residual products, quality water cleaning with minimal costs, at which excludes segregation harmful and harsh odor matter, rise output of biogas from methane tanks.

\section{Conclusions}

In Voronezh water basin for fight with algae, include with blue-green, used uncial method stocking water basin with fish. But, because of observed ecological condition near to emergency condition, it is possible to conclude, that this method in current situation is not efficient.

Pollution with dissolved organic matters leads at high temperature modes in summer to significant reproductive ability of cyanobacteriums. Thus in heated by solar radiation in shallow water it is advisable to periodically make catching blue-green algae by filtration unit with nozzle of milled cane. Moreover in it is supposed to make sorption water cleaning from heavy metals through their absorption by pored structure of rigid water flora. Utilization of collected biomass and filler of replaceable cartridges it could be make to execute through anaerobic fermentation, so to direct in methane tanks of city sewage treatment plants or to biogas station's reactors. Offered method of water basin cleaning allows to eliminate not only biogenic pollutions from top water layers, but additionally to clean shallow water from can, which is used for filling cartridges, that it is too positive influence on ecological situation.

\section{References}

1. Report of condition about environment on Voronezh region in 2013 year (Department of natural resources and ecology of Voronezh region, Voronezh, 2014)

2. G.S. Seydaliev, I.I. Kosinova, T.V. Sokolova, K.Yu. Silkin, Ecological management of territories of Voronezh water basin (Voronezh, 2017)

3. A.Yu. Skryabin, G.V. Popovyan, I.A. Tron, Water supply and sanitary technics 4, 5-8 (2017)

4. V.I. Scherbakov, B.M. Kumedov, Forest journal 4, 133-137 (2015)

5. E.D. Hetzuriani, T.S. Kolmakova, M.A. Akimenko, T.E. Hetzuriani, Vestnik Volgogradskogo gosudarstvennogo arkhitekturno-stroitelnogo universiteta, Series Stroitelstvo I arkhitektura 54(73), 156-164 (2018)

6. O.V. Nikitin, K.G. Antyukova, N.B. Kuzmin, M.B. Glyakina, V.Z. Latypova, Water cleaning, Water preparation, Water supply 7(139), 24-28 (2019)

7. F.T. Shumakov, Uchenye zapiski Tavricheskogo nationalnogo universiteta im V.I. Vernadskogo, Series "Geographia" 23(62), 286-295 (2010).

8. L. Moeller, A. Bauer, H. Wedwitschka, W. Stinner, A. Zehnsdorf, Energies 11(11), 3016 (2018) 
9. V. Nykyforov, M. Malovanyy, T. Kozlovs'ka, O. Novokhatko, S. Digtiar, EasternEuropean Journal of Enterprise Technologies 5/10 (83), 11-18 (2016)

10. N.V. Kuznetsova, N.A Drapalyuk., T.V. Shchukina, Conf. Series Materials Science and Engineering 687, 066076, (2019)

11. C. Rodriguez, A. Alaswad, J. Mooney, T. Prescott, Fuel Process, Technol 138, 765779 (2015)

12. M.P. Caporgno, R. Trobajo, N. Caiola, Renew, Energy 75, 374-380 (2015)

13. V.M. Shmandiy, V.V. Nikiforov, V.P. Alferov, E.V. Charlamova, V.A. Pronin, Hygien and sanitary 6, 35-37 (2010)

14. V.A. Mylutkin, S.A. Tolpekin, I.V. Borodulin, E.A. Agarkov, Sbornik statey po materialam II Vserossiyskoy (nationalnoy) nauchno-prakticheskoi konferencii, 104109 (2018)

15. I.N. Priadko, V.P. Mushchanov, H. Bartolo, N.I. Vatin, I.N. Rudnieva. Magazine of Civil Engineering. 2016. 65(5). Pp. 27-41. DOI:10.5862/MCE.65.3.

16. R.B. Orlovich, R. Nowak, N.I. Vatin, V.V. Bespalov. Magazine of Civil Engineering. 2018. 82(6). Pp. 95-102. DOI:10.18720/MCE.82.9.

17. M. Kuziakina, D. Gura, D. Zverok, E3S Web of Conferences 138, 02004 (2019). DOI: $10.1051 / \mathrm{e} 3$ sconf $/ 201913802004$

18. Y.V. Dubenko, D.A. Gura, E.E. Dyshkant, International Multi-Conference on Industrial Engineering and Modern Technologies, FarEastCon 2019, 8934179 (2019). DOI: 10.1109/FarEastCon.2019.8934179 